\title{
Symptoms of depression and quality of life of people living with HIV/AIDS
}

\author{
Renata Karina Reis ${ }^{1}$ \\ Vanderley José Haas $^{2}$ \\ Claudia Benedita dos Santos ${ }^{3}$ \\ Sheila Araujo Teles ${ }^{4}$ \\ Marli Teresinha Gimenez Galvão ${ }^{5}$ \\ Elucir Gir
}

This is a cross-sectional study conducted with 228 people living with HIV/AIDS in a municipality in the State of São Paulo during 2007 and 2008. The aims of this study were to investigate the intensity of the depressive symptoms in individuals with HIV/AIDS treated at two referral units in Ribeirão Preto, Brazil, and to compare the quality of life with the different degrees of intensity of the depressive symptoms in these individuals, according to gender. Data were collected through individual interviews, using the Beck Depression Inventory and HIV/AIDS Targeted Quality of Life (HATQOL). A total of $63(27.6 \%)$ patients with symptoms of depression (mild, moderate and severe) were detected. The women presented more severe symptoms of intensity of depression than men. Individuals with depressive symptoms presented lower scores of quality of life than individuals without these symptoms, with statistically significant differences between the means/ medians in most domains of the HATQOL. Healthcare professionals should offer integral care for people with HIV/AIDS, emphasizing the depressive symptoms.

Descriptors: HIV Infections; Depression; Quality of Life.

${ }^{1}$ RN, Ph.D. in Nursing, Professor, Escola de Enfermagem de Ribeirão Preto, Universidade de São Paulo, WHO Collaborating Centre for Nursing Research Development, SP, Brazil. E-mail: rkreis@eerp.usp.br.

2 Phycisist, Ph.D. in Sciences. E-mail: vjhaas@uol.com.br.

${ }^{3}$ Ph.D. in Statistics, Associate Professor, Escola de Enfermagem de Ribeirão Preto, Universidade de São Paulo, WHO Collaborating Centre for Nursing Research Development, SP, Brazil. E-mail: cbsantos@eerp.usp.br.

${ }^{4}$ RN, Ph.D. in Parasite Biology, Professor, Faculdade de Enfermagem, Universidade Federal de Goiás, Goiânia, GO, Brazil. E-mail: sheilaa@terra.com.br.

${ }^{5}$ RN, Ph.D. in Tropical Diseases, Adjunct Professor, Universidade Federal do Ceará, Fortaleza, CE, Brazil. E-mail: mgalvao@gmail.com.

${ }^{6}$ RN, Ph.D. in Nursing, Full Professor, Escola de Enfermagem de Ribeirão Preto, Universidade de São Paulo, WHO Collaborating Centre for Nursing Research Development, SP, Brazil. E-mail: egir@eerp.usp.br.

Corresponding Author:

Renata Karina Reis

Universidade de São Paulo. Escola de Enfermagem de Ribeirão Preto.

Av. Bandeirantes, 3900

Bairro: Monte Alegre

CEP: 14040-902 Ribeirão Preto, SP, Brasil

E-mail: rkreis@eerp.usp.br 


\section{Sintomas de depressão e qualidade de vida de pessoas vivendo com HIV/aids}

Trata-se de estudo de corte transversal, realizado com amostra composta por 228 pessoas vivendo com HIV/AIDS, em um município paulista, durante 2007 e 2008 . Os objetivos foram investigar a intensidade dos sintomas de depressão em indivíduos com HIV/AIDS, atendidos em duas unidades de referência, em Ribeirão Preto, SP, e comparar a qualidade de vida aos diferentes graus de intensidade dos sintomas de depressão nesses indivíduos, segundo o gênero. Os dados foram coletados por meio de entrevistas individuais, utilizando-se o inventário de depressão de Beck e HIV/AIDS Targeted Quality of Life (HATQoL). Detectou-se 63 (27,6\%) indivíduos com sintomas de depressão (leve, moderada e grave). As mulheres apresentaram sintomas de intensidade mais grave de depressão do que os homens. Indivíduos com sintomas depressivos apresentaram menores escores de qualidade de vida do que indivíduos com ausência desses sintomas, com diferenças estatisticamente significativas entre os valores médios/medianos, na maioria dos domínios do HATQoL. Profissionais de saúde devem oferecer assistência integral às pessoas com HIV/AIDS, valorizando os sintomas depressivos.

Descritores: Infecções por HIV; Depressão; Qualidade de Vida.

\section{Síntomas de depresión y calidad de vida de personas viviendo con HIV/Sida}

Se trata de un estudio de corte transversal realizado en 228 personas viviendo con HIV/Sida en un municipio del estado de Sao Paulo, durante 2007 y 2008. Los objetivos fueron investigar la intensidad de los síntomas de depresión en individuos con HIV/Sida atendidos en dos unidades de referencia en Ribeirao Preto, SP, y comparar la calidad de vida con los diferentes grados de intensidad de los síntomas de depresión en esos individuos, según el género. Los datos fueron recolectados por medio de entrevistas individuales, utilizando el Inventario de Depresión de Beck y HIV/AIDS Targeted Quality of Life (HATQoL). Se detectaron $63(27,6 \%)$ individuos con síntomas de depresión (leve, moderado y grave). Las mujeres presentaron síntomas de intensidad más grave de depresión que los hombres. Individuos con síntomas depresivos presentaron menores puntajes de calidad de vida que individuos con ausencia de esos síntomas, con diferencias estadísticamente significativas entre los valores medios/medianos en la mayoría de los dominios del HATQoL. Los profesionales de la salud deben ofrecer asistencia integral a las personas con HIV/Sida, valorizando los síntomas depresivos.

Descriptors: Infecciones por VIH; Depresión; Calidad de Vida.

\section{Introduction}

Quality of life (QoL) has become one of the major goals in studies regarding infection with the human immunodeficiency virus (HIV), because, due to advances in the treatment with the use of antiretrovirals, there has been a decrease of opportunistic infections, and an increase in the rates of survival(1). Given the change in the course of HIV infection to a chronic disease, improving the quality of life of people living with HIV/AIDS became one of the major goals of clinical practice and research in the $\operatorname{area}^{(2)}$. Studies of QoL among people living with HIV/
AIDS indicate that this is affected by many individual, cultural, social and emotional factors, related to the impact of the diagnosis and the treatment and quotidian living with a chronic disease(3). Different variables, such as gender, living and health conditions, have been studied for their relationship with QoL, however, some authors have shown that depression significantly affects all the QoL dimensions evaluated(4-5).

Depression is a common condition experienced by people living with chronic conditions, causing disability, 
affecting the evolution of the disease and interfering in the recovery and is considered a potential risk for increased morbidity and mortality for many medical conditions, including HIV/AIDS(6). HIV infection and psychiatric disorders present a complex relationship and have received special attention in the last decade, considering their impact in the personal, sexual, social and occupational lives of people living with HIV/AIDS(7). Among the various psychiatric disorders frequently identified in people living with HIV/AIDS, depression is the most prevalent. Apart from depression, it has been observed that stressful life events are associated with increased progression of the HIV/AIDS infection(8), which in turn, increase from three to five times the risk of developing depression ${ }^{(9)}$.

It has been well established that HIV/AIDS infection compromises the quality of life of the sufferer(10). However, other authors highlight a close relationship between depression and quality of life ${ }^{(5)}$, especially in individuals with chronic diseases(11). Considering that AIDS is a chronic disease and that its sufferers have a high risk of developing depressive symptoms, which has been associated with a decrease in the quality of life, the aims of this study were to investigate the intensity of the depressive symptoms in individuals with HIV/AIDS treated at two referral units in Ribeirao Preto, Brazil, and to compare the quality of life with the different degrees of intensity of depressive symptoms in these individuals, according to gender.

\section{Method}

This is a cross-sectional quantitative study, conducted at two services specializing in outpatient clinical care for people living with HIV/AIDS, located in the municipality of Ribeirão Preto-SP. These services have 500 registered patients, of these 228 (45.6\%) participated in the study. The study included individuals aged at least 18 years; HIV positive; with clinical and emotional conditions to respond to the questionnaires; having been attended at least once in the services participating in the study in the period from March 2007 to March 2008.

For the data collection, an individual interview was initially performed in rooms in the outpatient clinic, using a semi-structured script, developed specifically for this study, referring to sociodemographic data, age in years, gender (male, female), marital status (single, married, separated, widowed, living with partner, divorced) schooling in years of study, family income (in minimum wages), employment contract (yes, no, retired, unemployed). Next the Beck Depression Inventory (BDI) was applied to assess the intensity of the depressive symptoms and, finally, the HATQoL (HIV/AIDS Targeted Quality of Life) instrument to evaluate the quality of life of the participants. Several instruments are available to investigate the intensity of depressive symptoms, with the Beck Depression Inventory (BDI) one of the most used and translated into several languages ${ }^{(12)}$. The BDI is a self-administered scale, translated and validated in Brazil(13) and is composed of 21 items that contemplate cognitive depressive symptoms and attitudes.

The score for each category of the BDI ranges from zero to three, where zero corresponds to the absence of depressive symptoms and three to the presence of more intense symptoms. For the total score, up to 15 points signifies the absence or minimal presence of depressive symptoms, between 16 and 20 points there is evidence of depressive symptoms of mild to moderate intensity, and above 20 points indicates depressive symptoms of moderate to severe intensity. A score of 30 to 63 points indicates depressive symptoms of severe intensity. There are different cutoff points for depression, depending on the nature of the sample and the aims of the study. Also for undiagnosed samples, the guidelines are different, with scores greater than or equal to 18 giving an estimate of possible depression(13). In this study the categorization was used in which obtaining 21 points or more, could be considered as the presence of clinically significant depression ${ }^{(14)}$.

The HATQoL is a specific instrument, translated and validated in Brazil(15), for the evaluation of the quality of life of people living with HIV/AIDS. This instrument consists of 42 items divided into nine dimensions (Overall Function, Sexual Function, Disclosure Worries, Health Worries, Financial Worries, HIV Mastery, Life Satisfaction, Medication Worries and Provider Trust). This instrument was originally constructed from the personal suggestions of people living with HIV/AIDS, which implies that it evaluates domains that are important for this population(16). To answer each question, the individuals are compelled to think about their quality of life in the last four weeks. The answers are in the format of a Likert type scale of five points: "All the time", "most of the time", "part of the time", "a few times" and "never". In each domain, zero is the lowest score and 100 the best score possible. The higher the score, the lower the impact of the HIV infection on the quality of life of the individuals. In other words, the lower the score, the more affected the function, the greater the concern and the lower the life satisfaction ${ }^{(15)}$. Regarding the psychometric properties of the instrument, the Brazilian Portuguese version of the HATQoL was shown to be comprehensible and easily applied, with good construct 
validity and excellent reliability. Excellent results were found for the internal consistency, with Cronbach's alphas always above the cutoff value $(0.70)^{(16)}$. The authors highlight that this instrument can contribute to the evaluation of quality of life in the population with HIV/AIDS in Brazil.

For the analysis, the data were initially organized in an Excel spreadsheet, double entered and validated in order to obtain reliable data, free of transcription errors. Next, the data were exported into the statistical analysis program Statistical Package for the Social Sciences (SPSS) version 15.0. The Kolmogorov-Smirnov test was conducted to evaluate the normality of distributions of sample means of the scores of the domains of the QoL measurement. To analyze statistically significant differences between the means or medians of the quality of life scores in the different intensity of depressive symptoms groups, the ANOVA and Kruskal-Wallis tests were used. The Chi-square test was performed to verify the association between intensity of the depressive symptoms and gender. The descriptive level of significance used was $0.05(a=0.05)$.

The confidentiality of all the participants and the anonymity of the information were guaranteed and the data were collected with the consent of the participants, who all signed the Terms of Free Prior Informed Consent. The study was approved by the Ethics Committee of the University of São Paulo at Ribeirão Preto College of Nursing, according to protocol No. 0699/2006.

\section{Results}

The sociodemographic profile of the individuals studied is presented in Table 1 . Regardless of gender, almost half of the individuals were less than 40 years of age.

Table 1 - Distribution of the study participants, according to sociodemographic variables. Ribeirão Preto-SP, 2007 2008

\begin{tabular}{|c|c|c|c|c|c|c|}
\hline \multirow{2}{*}{ Variables } & \multicolumn{2}{|c|}{ Male } & \multicolumn{2}{|c|}{ Female } & \multicolumn{2}{|c|}{ Total } \\
\hline & $\mathbf{n}$ & $\%$ & $\mathbf{n}$ & $\%$ & $\mathbf{n}$ & $\%$ \\
\hline \multicolumn{7}{|l|}{ Age (years) } \\
\hline 20 to 29 & 16 & 13.1 & 9 & 8.5 & 25 & 11.0 \\
\hline 30 to 39 & 51 & 41.8 & 47 & 44.3 & 9 & 43.0 \\
\hline 40 to 49 & 34 & 27.9 & 32 & 30.2 & 66 & 28.9 \\
\hline 50 to 59 & 17 & 13.9 & 16 & 15.1 & 33 & 14.5 \\
\hline$\geq 60$ & 4 & 3.3 & 2 & 1.9 & 6 & 2.6 \\
\hline \multicolumn{7}{|l|}{ Marital status } \\
\hline Single & 72 & 59 & 32 & 30.2 & 104 & 45.6 \\
\hline Living with partner & 18 & 14.8 & 29 & 27.4 & 47 & 20.6 \\
\hline Married & 19 & 15.6 & 19 & 17.9 & 38 & 16.7 \\
\hline Separated & 7 & 5.7 & 7 & 6.6 & 14 & 6.1 \\
\hline Widowed & 1 & 0.8 & 12 & 11.3 & 13 & 5.7 \\
\hline Divorced & 5 & 4.1 & 7 & 6.6 & 12 & 5.3 \\
\hline \multicolumn{7}{|l|}{ Schooling } \\
\hline Illiterate & 4 & 3.3 & 8 & 7.5 & 12 & 5.3 \\
\hline Incomplete Elementary Education & 49 & 40.2 & 57 & 53.8 & 106 & 46.5 \\
\hline Complete Elementary Education & 17 & 13.9 & 23 & 21.7 & 40 & 17.5 \\
\hline Complete High School Education & 41 & 33.6 & 16 & 15.1 & 57 & 25.0 \\
\hline Complete Higher Education & 11 & 9.0 & 2 & 1.9 & 13 & 5.7 \\
\hline \multicolumn{7}{|l|}{ Income (minimum wage) } \\
\hline No income & 13 & 10.7 & 18 & 17.0 & 31 & 13.6 \\
\hline$\leq 1$ & 12 & 9.8 & 35 & 33.0 & 47 & 20.6 \\
\hline 1.1 to 3 & 69 & 56.6 & 49 & 46.2 & 118 & 51.8 \\
\hline 3.1 to 5 & 17 & 13.9 & 3 & 2.8 & 20 & 8.8 \\
\hline$>5$ & 11 & 9.0 & 1 & 0.9 & 12 & 5.3 \\
\hline \multicolumn{7}{|l|}{ Employment contract } \\
\hline No & 42 & 34.4 & 55 & 51.9 & 97 & 42.5 \\
\hline Yes & 48 & 39.3 & 33 & 31.1 & 81 & 35.5 \\
\hline Unemployed & 16 & 13.1 & 13 & 12.3 & 29 & 12.7 \\
\hline Retired & 16 & 13.1 & 5 & 4.7 & 21 & 9.2 \\
\hline
\end{tabular}

* the minimum monthly wage during the study period was $\mathrm{R} \$ 380.00$ (three hundred and eighty reais) 
The evaluation using the Beck Depression Inventory identified that $63(27.6 \%)$ individuals presented symptoms of depression; being 13 (5.7\%) with mild symptoms, 29 (12.7\%) with moderate and 21 (9.2\%) with severe symptoms. When comparing the presence of depressive symptoms between the genders, statistically significant differences were verified between men and women, since the women presented symptoms of a more severe intensity of depression than the men (Table 2).

Table 2 - Distribution of the participants of the study according to intensity of depressive symptoms, according to the Beck Depression Inventory and gender and the value of the statistical significance $p$ associated with the Chi-square test. Ribeirão Preto-SP, 2007 - 2008

\begin{tabular}{|c|c|c|c|c|c|c|c|c|}
\hline \multirow{2}{*}{ Symptoms of Depression } & \multicolumn{2}{|c|}{ Male } & \multicolumn{2}{|c|}{ Female } & \multicolumn{2}{|c|}{ Total } & \multirow{2}{*}{$x^{2}$} & \multirow{2}{*}{$\mathbf{p}$} \\
\hline & $n$ & $\%$ & $\mathbf{n}$ & $\%$ & $\mathbf{n}$ & $\%$ & & \\
\hline Absent $(\leq 15)^{\star}$ & 97 & 79.5 & 68 & 64.0 & 165 & 72.4 & \multirow{5}{*}{12.1} & \multirow{5}{*}{$<0.01$} \\
\hline Mild (16 to 20$)$ & 7 & 5.7 & 6 & 6.0 & 13 & 5.7 & & \\
\hline Moderate (>20 to 29 ) & 14 & 11.5 & 15 & 14.0 & 29 & 12.7 & & \\
\hline Severe $(>30)$ & 4 & 3.3 & 17 & 16.0 & 21 & 9.2 & & \\
\hline Total & 122 & 100 & 106 & 100 & 228 & 100 & & \\
\hline
\end{tabular}

* BDI Score

Regarding the quality of life domains of the HATQOL, when compared with symptoms of depression in the individuals investigated, an inverse relationship was identified, i.e. the greater the intensity of symptoms, the worse the QoL in most domains except in the domains "Disclosure Worries" and "Provider Trust" in which no statistically significant associations were identified (Table 3).

Table 3 - Standardized values of means and medians of the domains of the HATQoL scale in the study participants, according to intensity of depressive symptoms and their statistical significance values $p$, associated with the ANOVA or Kruskal-Wallis test. Ribeirão Preto-SP, 2007 - 2008

\begin{tabular}{|c|c|c|c|c|}
\hline \multirow{3}{*}{ Domains of the HATQoL } & \multicolumn{3}{|c|}{ Depressive Symptom } & \multirow{3}{*}{$p$} \\
\hline & Absent & Mild to moderate & Severe & \\
\hline & Mean/Median & Mean/Median & Mean/Median & \\
\hline Overall Function & $81.8 / 89.3$ & $57.0 / 55.4$ & $45.9 / 39.3$ & $<0.001$ \\
\hline Sexual Function & $68.4 / 75.0$ & $51.4 / 50.0$ & $40.5 / 50.0$ & $<0.001$ \\
\hline Disclosure Worries & $31.5 / 25.0$ & $30.5 / 20.0$ & $35.5 / 40.0$ & 0.826 \\
\hline Health Worries & $58.2 / 60.0$ & $29.5 / 27.5$ & $27.6 / 25.0$ & $<0.001$ \\
\hline Financial Worries & $36.9 / 31.2$ & $24.7 / 12.5$ & $15.5 / 6.2$ & $<0.001$ \\
\hline HIV Mastery & $71.8 / 66.7$ & $58.7 / 58.3$ & $46.4 / 33.3$ & $<0.001$ \\
\hline Life Satisfaction & $78.5 / 78.1$ & $55.1 / 57.8$ & $37.8 / 31.2$ & $<0.001$ \\
\hline Medication Worries & $86.5 / 93.7$ & $74.3 / 75.0$ & $67.9 / 65.6$ & $<0.001$ \\
\hline Provider Trust & $96.7 / 100$ & $92.5 / 100$ & $95.2 / 100$ & $0.103^{(\mathrm{a})}$ \\
\hline
\end{tabular}

(a) Kruskal-Wallis test

\section{Discussion}

The results of this study indicate a prevalence of depressive symptoms of $27.6 \%$ according to the BDI. However, it was evident that, when comparing the presence of depressive symptoms between the genders, statistically significant differences were verified between men and women, since the women presented symptoms of a more severe intensity of depression than the men. Another study in Brazil also indicated a high prevalence of $25.8 \%$ of symptoms of depression among women infected by HIV/AIDS, much higher values when compared with the general female population ${ }^{(9)}$. These results indicate the necessity of comprehending the factors that increase the risk of depression among women, considering that rates of depression in the world vary from $4 \%$ to $10 \%$ 
in the general population, however, throughout life, the prevalence of depression among women is higher than among men, with rates varying from $10 \%$ to $25 \%$ in women and $5 \%$ to $12 \%$ in men ${ }^{(17)}$.

It is estimated that depression affects $22 \%$ to $45 \%$ of people with HIV/AIDS ${ }^{(17)}$, with social and psychological factors, such as difficulties in emotional and sexual relationships, marital conflict and social exclusion having been suggested as possible causes of depression in the HIV seropositive population(8). Moreover, depression has been associated with alterations in immunological function, with decreases in the activity of Natural Killer cells and CD8 lymphocytes(8) impacting the progression of the HIV infection ${ }^{(6)}$. Nevertheless, the diagnosis and treatment of depression in people living with HIV/AIDS occur in only $40 \%$ to $50 \%$ of the cases ${ }^{(11)}$. The variability observed between the rates reported in the literature can be attributed to factors such as the instrument used and the characteristics of the study population, the location in which the research was performed and the stage of disease ${ }^{(18)}$.

Depression is one of the most prevalent and least diagnosed psychiatric disorders among individuals living with HIV/AIDS, and when compared to the general population is significantly higher in these individuals ${ }^{(19)}$, with rates approximately twice as high(20). The data also confirm the negative impact of depression in all domains of the HATQOL, except in the domains and Provider trust and Disclosure worries. It was observed that the greater the intensity of the depressive symptoms the worse the QoL scores. Studies carried out in Porto Alegre-RS with the population treated at a primary care unit and with people living with HIV/AIDS also found similar results, showing that the presence of depressive symptoms seems to negatively affect the quality of life in many of the evaluated dimensions ${ }^{(5,21)}$. The association between depression and viral infection is not new ${ }^{(22)}$, however, in Brazil, studies that evaluate the relationship between quality of life and depressive symptoms are still very incipient ${ }^{(23)}$.

Other studies performed in Brazil show that the quality of life of people living with HIV/AIDS is related to many variables ${ }^{(5,15)}$. There is significant evidence in the literature that the depressed individuals presented significant impairment in quality of life and physical and mental functioning, considering that depressive disorders affect many domains of the overall evaluation of quality of life ${ }^{(4)}$, considered one of the strongest predictors of lower quality of life of people with HIV/ AIDS. Other authors also highlight that depression has a negative impact on all the dimensions of quality of life studied, in addition to being associated with poor adherence to the antiretroviral treatment ${ }^{(24)}$, and a greater perception of the stigma associated with HIV(25). Depression negatively impacts the quality of life in different populations with chronic disease ${ }^{(26)}$. Depressive disorders complicate the course of any disease through a variety of mechanisms, which increase the pain, interfere in the adherence to treatment, decrease social support and disrupt the humoral and cell-mediated immunological systems. Individuals with chronic disease who are depressed present more disability than those who are not depressed(27).

Depressive disorders are associated with serious consequences in terms of mortality and morbidity, causing loss of productivity and interfering in interpersonal relationships. The long-term effects of depression are as severe as those observed in diverse general medical conditions, and are likely to have adverse effects on longevity and well-being(5). However, despite the negative impact of depression for the progression of HIV/ AIDS and in the quality of life of people living with HIV/ AIDS, the diagnosis and treatment do not occur in $50 \%$ to $60 \%$ of the cases ${ }^{(12)}$. The diagnosis of depression can often be difficult due to the imprecise boundary between its manifestations in clinical and subclinical forms, especially in individuals with HIV. In these individuals, the difficulties in the diagnosis of depression become more severe, given that clinical conditions common in depression, such as fatigue, decreased appetite, sleep disturbance and weight loss, are frequently found in individuals living with HIV/AIDS ${ }^{(28)}$. In addition, there are other barriers for the diagnosis of depression among HIV-infected individuals, including the difficulty for the individual to talk about their emotions with health professionals and the comprehension by the health professionals that depression is a normal reaction arising from HIV seropositivity ${ }^{(29)}$.

Given the impact of the antiretrovirals on the survival of those infected by HIV/AIDS, the adherence to the treatment is the center of the interventions of the professionals. While medical treatment has been making undeniable progress, the emotional support that encourages better confrontation of the emotional issues, fundamental to self-care, still suffers the consequences of the professionals being unprepared to address the psychosocial aspects that arise from HIV seropositivity ${ }^{(29)}$. In this sense, it is essential that clinicians, nurses, psychologists and other health professionals comprehend and identify the associated factors and the determinants 
of depression in the context of HIV/AIDS infection, given its impact on the quality of life of HIV seropositive people with depressive symptoms.

\section{Final considerations}

To describe the intensity of symptoms of depression and their relationship with gender and with the domains of quality of life in the population infected by HIV/AIDS are important steps to develop therapeutic interventions and psychosocial support for these individuals, directed not only towards the treatment, but towards the prevention of depressive episodes, considering the high prevalence of depression and its consequences on the quality of life of HIV-infected individuals, as well as its impact on the evolution of the HIV infection. Health professionals should be aware of this issue, aiming to promote the mental health of the people living with HIV/ AIDS. In this sense the nurse exercises a fundamental role and can help the healthcare team in the prevention, diagnosis and treatment of this important morbidity among people with HIV/AIDS, as well as in the provision of integral care to these individuals.

\section{References}

1. Trépanier LL, Rourke SB, Bayoumi AM, Halman $\mathrm{MH}$, Krzyzanowski S, Power C. The impact of neuropsychological impairment and depression on health-related quality of life in HIV-infection. J Clin Exp Neuropsychol. 2005;27:1-15.

2. O'Connel K, Skevington S, Saxena S. Preliminary development of the world Health Organization's Quality of Life HIV instrument (WHOQOL HIV): analysis. Soc Sci Med. 2003;57(7):1259-75.

3. Perez IR, Bãno RJ, Ruz MAL, Jimenez AA, Prados MC, Liaño JP, et al. Health-related quality of life of patients with HIV: impact of sociodemographic, clinical and psychosocial factors. Qual Life Res. 2005;14:1301-10. 4. Zimpel RR, Fleck MPA. Qualidade de vida em pacientes com HIV/aids: conceitos gerais e resultados de um estudo brasileiro. In: Fleck $M$, organizador. $A$ Avaliação de qualidade de vida: guia para profissionais de saúde. Porto Alegre: Artmed; 2008. p. 157-67.

5. Berlim MT, Brenner JK, Caldieraro MAK, Pargendler JS, Fleck MPA. Qualidade de vida em deprimidos. In: Fleck MPA, organizador. A avaliação da qualidade de vida: guia para profissionais da saúde. Porto Alegre: Artmed; 2008.
6. Cruess DG, Douglas SD, Pettito JM, Have T, Gettes $D$, Dubé $B$, et al. Association of resolution of major depression with increased natural killer cell activity among HIV-seropositive women. Am J Psyquiatry. 2005; 162:11.

7. Chandra PS, Desai G, Ranjan R. HIV and Psychiatric disorders. Indian J Med Res. 2005;121:451-67.

8. Evans DL, Leserman J, Perkins DO, Stern RA, Murphy $C$, Zheng $B$, et al. Severe life stress as a predictor of early disease progression in HIV infection. Am J Psychiatry. 1997;154(5):630-4.

9. Mello VA, Malbergier A. Depression in women infected with HIV. Rev Bras Psiquiatr. 2006;38(1):10-7.

10. Evans DL, Have TRT, Douglas SD, Getes DR, Morrison M, Chiappini M, et al. Association of depression with load, CD8 T lymphocytes, and natural killer cells in women with HIV infection. Am J Psychiatry. 2002;159:1752-9. 11. Malbergier A, Schoffel AC. Tratamento de depressão de indivíduos infectados pelo HIV. Rev Bras Psiquiatr. 2001;23(3): 160-7.

12. Gorenstein C, Andrade L. Inventário de Depressão de Beck - propriedades psicométricas da versão em português. In: Gorenstein C, Andrade L, Zuardi AW, editors. Escalas de avaliação clínica em psiquiatria de psicofarmacologia. São Paulo: Lemos Editorial; 2000. p. 89-95.

13. Barroso J, Snadelowski M. In the Field the Beck depression Inventory. Qual Health Res. 2001;11:491504.

14. Beck AT, Beamesderfer A. Assessment depression: the Depression Inventory. In: Pichot $P$, OlivierMartin R, editors. Psychological measurements in psychopharmacology. Oxford (ENG): S. Karger; 1974. p. 151-69.

15. Galvão MTG, Cerqueira ATAR, Machado JM. Avaliação da qualidade de vida de mulheres com HIV/Aids através do HAT-Qol. Cad Saúde Pública; 2004;20(2):430-7.

16. Soárez PC, Castelo A, Abrão P, Holmes W C, Ciconelli RM. Tradução e validação de um questionário de qualidade de vida em AIDS no Brasil. Rev Panam Salud Publica/Pan Am J Public Health. 2009;25(1):69-76.

17. Penzak SR, Reddy YS, Grimsley SR. Depression in patients with HIV infection. Am J Health Syst Pharm. 2000;57(4):376-86; 387-9

18. Schimitt JHL, Silava da RM. Prevalência de Sintomas Depressivos em Pacientes Portadores do HIV/aids em um Hospital de Referência na Cidade de FlorianópolisSC. Arq Catarinenses Med. 2009;38(2):90-7. 
19. .Patterson K, Young C, Woods SP, Vigil O, Grant I, Atkinson $\mathrm{JH}$. Screening for major depression in persons with HIV infection: the concurrent predictive validity of the Profile of Mood Estates Depression-Dejection Scale. Int J Methods Psiquiatr Res. 2006;15(2):75-82.

20. Ciesla JA, Roberts JE. Meta-analysis of the relationship between HIV infection and risk for depressive desorders. Am J Psychiatry. 2001;158(5):725-30.

21. Corso AN, Costa Lda S, Fleck MP, Heldte E. Impact of depressive symptoms in the quality of life of basic health care service users. Rev Gauch Enferm. junho 2009;30(2):257-62.

22. Stumpf $B P$, Rocha FL, Proietti ABFC. Infecções virais e depressão. J Bras Psiquiatr. 2006;55(2):132-41.

23. Canini SRMS, Reis RB, Pereira LA, Gir E, Pelá NTR. Qualidade de vida de indivíduos com HIV/aids: revisão de literatura. Rev. Latino-Am. Enfermagem. $2004 ; 12(6): 940-5$.

24. Jia H, Uphold CR, Wu S, Chen GJ, Duncan PWA. Predictors of change in health- related quality of life among men with infection in the HAART era. AIDS Patient Care STDS. 2005;19(6):495-505.

25. Willians P, Narciso L, Browne G, Roberts J, Weir $R$, Gafni A. The prevalence, correlates, and costs of depression in people living with HIV/AIDS in Ontario: implications for service directions. AIDS Educ Prev. 2005;17(2):119-30.

26. Li L, Lee S, Thammawijaya P, Jiraphongsa C, BorusRotheram MJ. Stigma, social Support, and depression among people living HIV in Thailand. AIDS Care. 2009;21(8):1007-13.

27. Cruz LN, Polanski CA, Fleck MA. Qualidade de vida em cardiopatia isquêmica. In: Fleck MPA, organizador. A Avaliação de qualidade de vida: guia para profissionais de saúde. Porto Alegre: Editora Artmed; 2008. p. 197-207.

28. Teng CT, Humes EC, Demetrio FN. Depressão e comorbidades clínicas. Rev Psiquiatr Clín. 2005;32(3):149-59.

29. Saldanha AAW, Figueiredo MAC, Coutinho MP. Atendimento Psicossocial à Aids: a busca pelas questões subjetivas. J Bras Doenças Sex Transm. 2004;16(3):84-91. 